\title{
VÝPRAVA DO INDONÉSIE S MORAVSKÝM ZEMSKÝM MUZEEM
}

Výstava Tajemná Indonésie -

TAMTAMY ČASU - Nová Guinea je pořádána na počest cestovatele Miroslava Zikmunda a byla otevřena v Brně v Moravském zemském muzeu 14. 2. 2019 v den, kdy oslavil krásných 100 let. Navštívit ji můžete do 31. 5. 2019 v Paláci šlechtičen na ulici Kobližné. ${ }^{1}$

Na výstavě jsou k vidění historické materiály od nejznámější cestovatelské dvojice Jiří Hanzelka \& Miroslav Zikmund. Tito cestovatelé procestovali celý svět a publikovali o svých cestách desítky knih. Na Novou Guineu cestovali právě v klíčový moment, kdy z území odcházeli Holand’ané a vzniklo nové území Irian Jaya. Na této cestě vznikl rukopis, který v minulém režimu nebylo možné publikovat, avšak dnes je spolu s dalšími cestopisnými rukopisy plně $\mathrm{k}$ dispozici. ${ }^{2}$

Skvostné velkoformátové fotografie na výstavě jsou od cestovatele Rudolfa Švaříčka, který uspořádal řadu výprav na exotické ostrovy a do jiných světových destinací. Společně s Jitkou Popelkovou založili v roce 1995 Cestovní kancelář Livingstone, jejímiž výstupy jsou expedice, výstavy a také publikace. Další osobností spolupracující na výstavě je známý český spisovatel PhDr. Miloslav Stingl, který vycestoval na Novou Guineu celkem

1 Tajemná Indonésie - Tamtamy času - Nová Guinea. In Moravské zemské muzeum [online]. Brno: Moravské zemské muzeum, 2019 [cit. 201905-10]. Dostupný z www: <http://www.mzm.cz/ palac-slechticen/tajemna-indonesie-tamtamy-casu-nova-guinea/>

2 Tamtamy času. Tajemná Indonésie - Nová Guinea. Svět, o kterém jste si mysleli, že už neexistuje. Brno, 2019. 48 s. Tištěný průvodce.

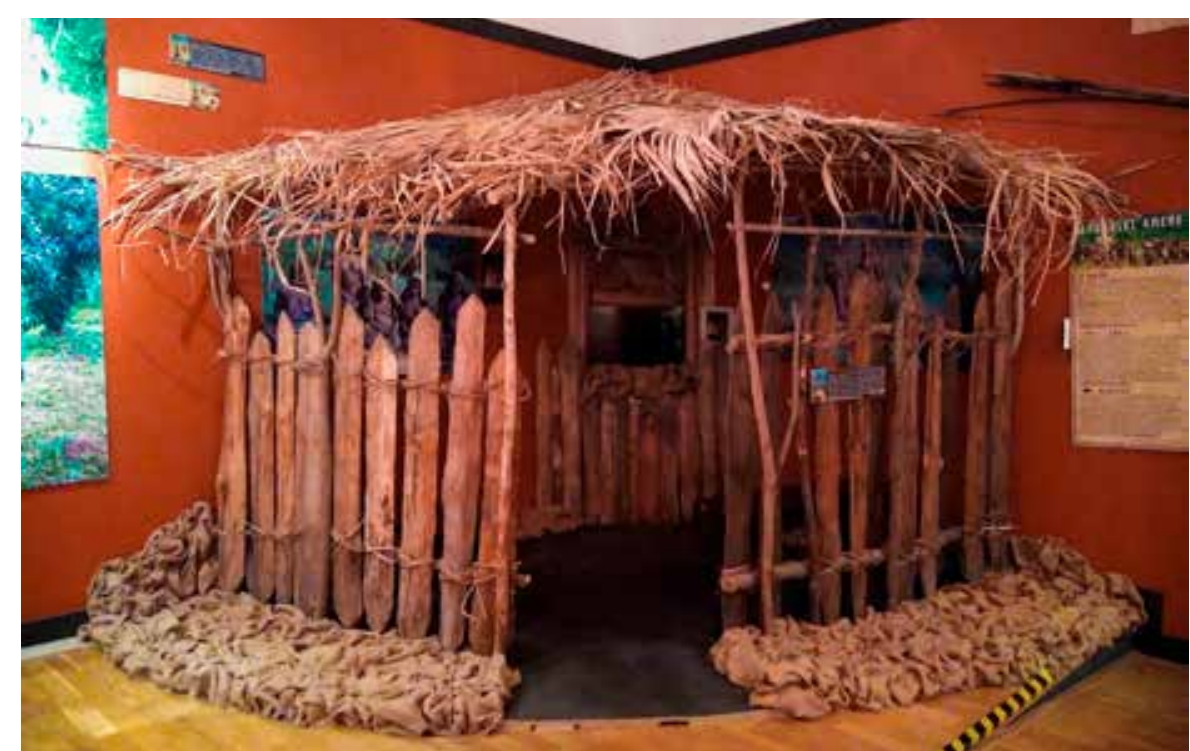

Obr. 1: Rekonstrukce chýše kmene Kombai (foto: Lenka Tranová, 2019)

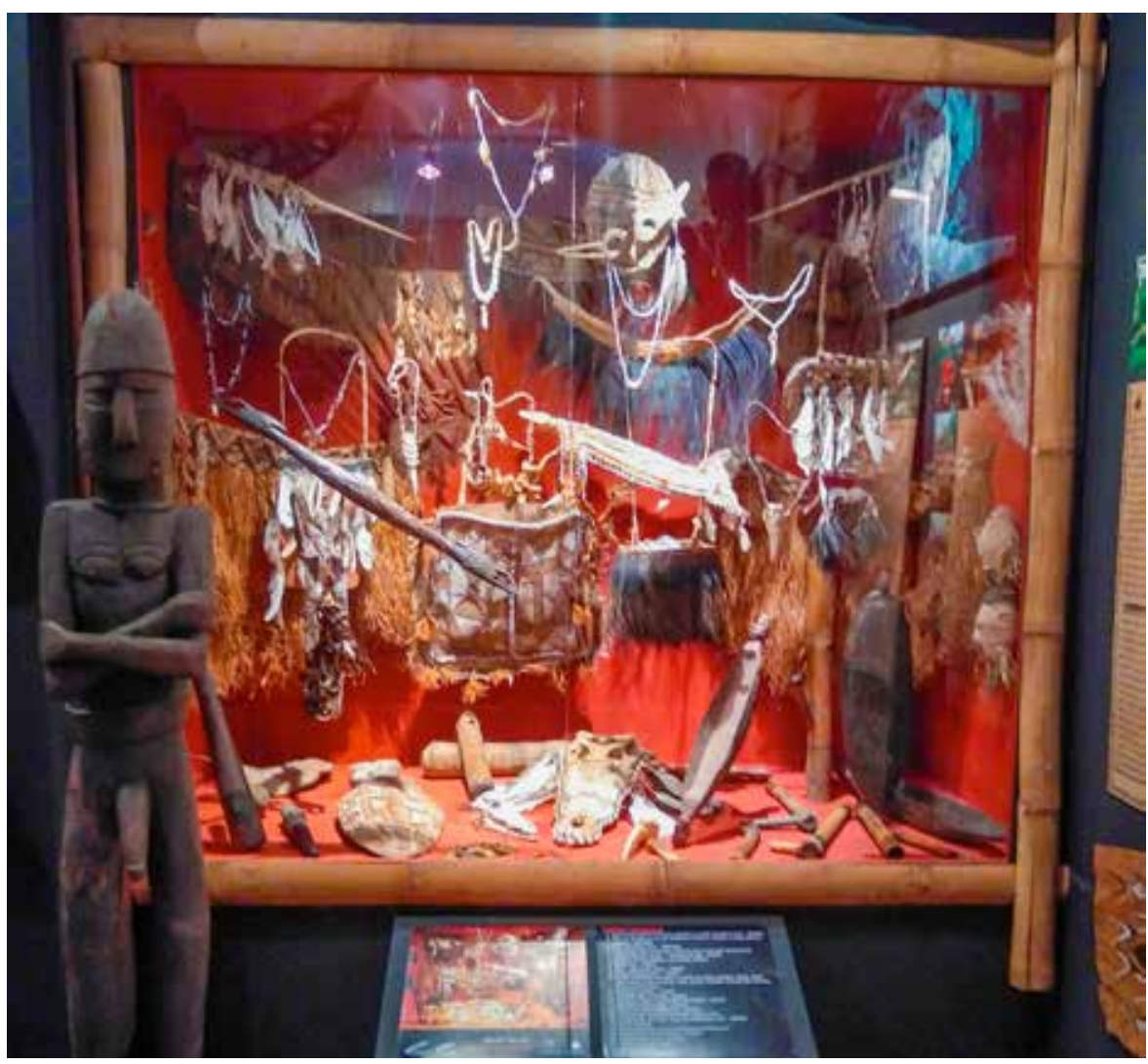

Obr. 2: Ukázka exponátů ve vitríně (foto: Lenka Tranová, 2019) 


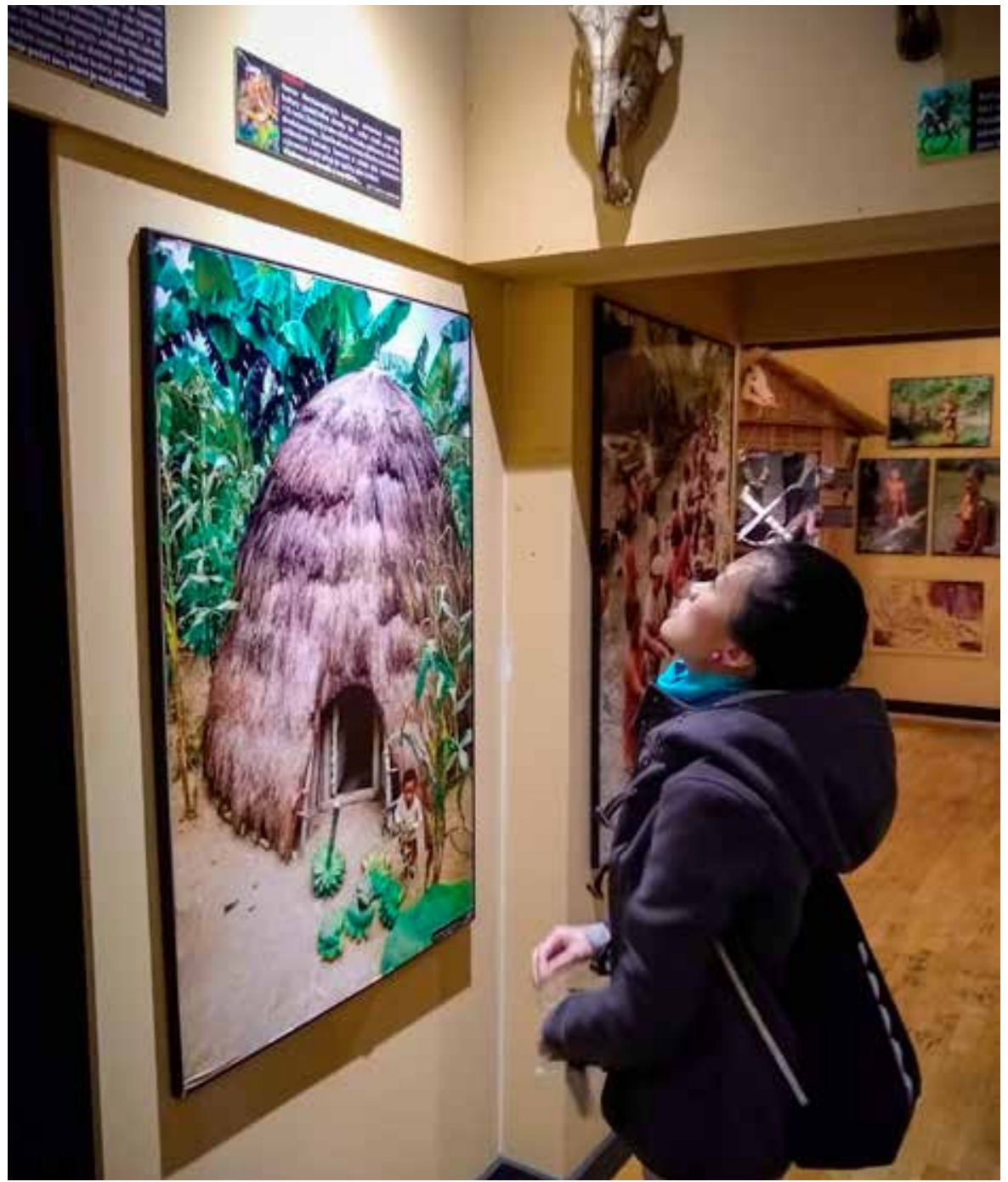

Obr. 3: Ukázka umístění textu ve výstavě (foto: Barbora Klimentová, 2019)

jedenáctkrát v rozmezí let 19671998. Po celou dobu svých výprav střádal nové informace o životě místních etnik, který je pro Evropany těžko představitelný. Zajímal se o lovce lebek, kanibalismus, každodenní život domorodců, o jejich nemoci i milostný život.

Výstava ${ }^{3}$ nás hned při otevření vchodových dveří Paláce šlechtičen přenese do kouzelných míst Indonésie, díky ukázce bambusové konstrukce s vyřezávanými totemy, skrze kterou návštěvník projde $\mathrm{k}$ pokladně. $\mathrm{V}$ prvních dvou míst-

3 Tajemná Indonésie [online]. Brno: CK Livingstone, 2017 [cit. 2019-05-10]. Dostupný z www: $<$ https://tajemnaindonesie.cz/>. nostech jsou informace a fotografie týkající se cestovatelů Zikmunda a Hanzelky a ukázky fotografií Švaříčka, na některých z nich jsou zachyceni např́klad muži s liánou přivázanou k noze, skákajíce $\mathrm{z}$ věží, aby zajistili úrodu celému kmeni. Tyto místnosti jsou doplňkové, proto je personál muzea doporučuje navštívit až na závěr.

Hlavní část celé výstavy se nachází dále a je rozdělena do pěti místností. V první řadě se dozvídáme obecné informace o Indonésii a místní fauně a flóře. $Z$ celkového počtu tří set domorodých etnik, nacházejících se na tomto kontinentu, jsou zde představeny ty kmeny, které měli autoři výstavy možnost navštívit.

Díky autentickým exponátům si návštěvník lépe utvoří představu o běžném životě domorodců, jejich tradicích a zvycích. Zajímavá je kupříkladu věrohodná rekonstrukce chýše kmene Kombai (obr. 1), do které se lze posadit a zhlédnout krátký dokument natočený přímo ve vesnici tohoto kmene. Dalšími vystavenými exponáty jsou různorodé korály, totemy, dřevěné zbraně, rituální masky, šperky z kostí a zubů zvírrat i lidských obětí.

Ačkoliv jsou předměty nesmírně zajímavé, vzhledem k množství kmenů je jejich počet možná příliš vysoký a návštěvník si je stěží dává do souvislostí, které předměty a které informace patří ke konkrétním kmenům. Umístění objektů ve vitrínách se zdá být mírně chaotické. Ačkoli je jejich popis šikovně řešený $\mathrm{v}$ podobě fotografie vitríny s číslováním, stále se v ní nachází předměty, které odvádí pozornost (obr. 2).

Zaměříme-li se na textovou stránku výstavy, může být návštěvník poněkud přehlcen $\mathrm{v}$ důsledku zbytečně se opakujících informací. Malou výtkou může být také nevhodné vysoké - umístění některých částí textu i předmětů (obr. 3).

Muzeum nabízí komentované prohlídky pro žáky a studenty každou středu, pro veřejnost ve vybraných dnech (čtvrtky) nebo po domluvě. Výstava určitě stojí za zhlédnutí, doporučujeme vyhradit si na ni alespoň dvě hodiny.

\section{BARBORA KLIMENTOVÁ - LENKA TRANOVÁ}

studentky muzeologie,

Ústav archeologie a muzeologie, Filozofická fakulta, Masarykova univerzita, Brno, Česká republika 